\title{
Molecular Identification of Meloidogyne javanica occurring in Upper Egypt Based Polymerase Chain Reaction (PCR) Assays
}

\author{
El-Sagheer, A.M. \\ Agric. Zool. and Nematol. Dept., Fac.Agric., Al-Azhar Univ., Assiut, Egypt \\ Corresponding author email: atefelsagheer@azhar.edu.eg
}

\begin{abstract}
Molecular diagnosis represents one of the important trends in the confirmation of morphological identification to the root-knot nematodes which one of the most global pathogens. In this context, current study aimed to describe Meloidogyne javanica occurring in cucumber plants in Assiut governorate (Upper Egypt) using the random amplified polymorphic DNA-Polymerase Chain Reaction (RAPD-PCR) assay. Four mitochondrial and specific-specific sequences characterized amplified regions (SCAR) primers were used. The results showed that the SCAR primers, Fjav/Rjav and Far/Rar were efficiently amplified with $670 \mathrm{bp}$ and $517 \mathrm{bp}$, respectively. On the contrary, the mitochondrial primers did not show any results. In conclusion, the present study recommended the SCAR primers as effective identified primers for the species of Meloidogyne javanica.
\end{abstract}

Keywords: Root-knot nematode, Meloidogyne javanica, RAPD-PCR, SCAR, Mitochondrial

\section{INTRODUCTION}

Identification of Meloidogyne species is increasingly important in designing the effective nematode management practices, such as crop rotation, plant resistance and agricultural quarantine purposes (Zijlistra, 2000; Zijlistra and Van Hoof, 2006). Molecular identification has confirmed the validity of a number of classical nematode species which were classified according to the molecular evidence (Holterman et al., 2006). Furthermore, incorporation of morphological and molecular analyses of nematodes provides a more effective means of identification (Thomas et al., 1997). The differentiation between Meloidogyne species can be very difficult using morphological and biological trait data because they are quite similar and can be regularly confused in inaccurate taxonomic comparisons (Coyne et al., 2009). The difficulty in identifying nematode species is due not only to the choice of the most accurate and adapted method, but also to several parameters that can affect the performance of the identification, such as the small size of the worms, the high number and diversity of nematodes in a sample, and/or the absence of specific morphological features (Chitwood, 2003). Microscopic examination, especially in groups such as nematodes with obvious structural differences, requires more significant technical and taxonomic expertise (De Ley et al., 2005). Traditionally, identification and description of Meloidogyne species was based mainly on perineal pattern morphology and supported by other morphological characteristics of female, juveniles (J2), and males (Karssen, 2002). The random amplified polymorphic DNA- 
Polymerase Chain Reaction (RAPD-PCR) as a rapid technique was successfully used in identification of the root-knot nematode, M. javanica (Cenis, 1993)

Different methods based on DNA and PCR, such as RAPD, restriction fragment length polymorphism (RFLP), sequence characterized amplified regions (SCAR), Multiplex PCR, and amplified fragment length polymorphism (AFLP) have been developed and successfully used for identifying many of the nematode species (Tigano et al., 2010). A number of specific primers have been developed for the identification of Meloidogyne species based on species-specific DNA fragments (Dong et al., 2001). The species-specific sequence characterized amplified regions (SCAR- PCR) primers work at higher annealing temperatures than RAPD-PCR primers (Castagnone et al., 1999). Therefore, the aim of the current study is the identification of a root-knot nematode species collected from Upper Egypt based on RAPD-PCR techniques.

\section{MATERIALS AND METHODS}

\section{Propagation of Meloidogyne javanica (Treub, 1885) Chitwood, 1949 in pure culture}

A total of 50 naturally infested cucumber roots (cv. Hayel ${ }^{\circledR}$ ) were collected from four localities in Assiut province (Abo-Teg, Assiut, Mangabad and Manfalot). A pure stock culture of the root-knot nematode $M$. javanica was prepared from infested roots. Individual egg masses with their mature females were removed from root tissues. Then, each egg mass was placed in a small glass capsule containing fresh water. The females from which egg masses were collected were preserved in glass capsules containing 4\% formaldehyde solution. Each egg mass was identified to species level by perineal pattern according to Taylor and Netscher (1974). The nematodes were then transferred to $25-\mathrm{cm}$ clay pots filled with-steam sterilized sandy loam soil planted with a seedling of cucumber $\mathrm{cv}$. Hayel. Inoculated pots were placed in a greenhouse and watered as needed. After two months of inoculation, infected roots were then chopped and used as a source of inoculation for other series of clean cultivar Pritchard tomato seedlings. The previous procedure was repeated to obtain enough quantities of inoculation from stock cultures on the cucumber.

\section{Identification of Meloidogyne species}

Species of Meloidogyne were identified again on the basis of perineal pattern system of the mature females. Individuals of mature females of each root sample were singly transferred on slides, each one with a drop of hot lactophenol solution/slide. Then the posterior end of each mature female was cut off using a sharp razor blade and trimmed down to the area showing the pattern. Slides were gently covered with a clean cover slip and sealed with finger nail-polish (Taylor and Netscher, 1974). All preparations were examined using Carson digital microscope (model zPix MM-940). Meloidogyne species was identified according to morphological features described by Chitwood (1949) and Sasser (1954).

\section{Molecular identification}

\section{Selection of primers}

According to Powers and Harries (1993), mitochondrial encoded gene cytochrome oxidase subunit II had been used for identifying the five common Meloidogyne species whereas species-specific nuclear encoded have been used for the rapid identification of root-knot nematodes by SCAR-PCR (Munthali et al., 1992). In the present study, the populations found in 4 different localities were screened using four mitochondrial and nuclear encoded species specific primers as listed in Table (1). 
Table 1: Nucleotide sequence of primer used for each mitochondrial and SCAR derived from the RAPD markers to identify the root-knot nematodes, Meloidogyne javanica.

\begin{tabular}{|c|l|c|}
\hline Primers & \multicolumn{1}{|c|}{ Sequence } & $\begin{array}{c}\text { Reference } \\
\text { sources }\end{array}$ \\
\hline $\begin{array}{c}\text { C2F3/Mel450R } \\
\text { (mitochondrial) }\end{array}$ & $\begin{array}{c}\text { 5'-GGTACAATGTTCAGAAATTTGTGG-3' } \\
\text { 5'-ATCCTAATAATAAATAAAAATG-3' }\end{array}$ & $\begin{array}{c}\text { Powers and } \\
\text { Harris, 1993 } \\
\text { and Meng et } \\
\text { al., 2004 }\end{array}$ \\
\hline $\begin{array}{c}\text { Mjf/Mjr } \\
\text { (SCAR) }\end{array}$ & $\begin{array}{c}\text { 5'-ACGCTAGAATTCGACCCTGG-3' } \\
\text { 5'-GGTACCAGAAGCAGCCATGC-3' }\end{array}$ & \\
\hline $\begin{array}{c}\text { Far/Rar } \\
\text { (SCAR) }\end{array}$ & $\begin{array}{c}\text { 5'-TCGGCGATAGAGGTAAATGAC-3' } \\
\text { 5'-TCGGCGATAGACACTACAAACT-3' }\end{array}$ & $\begin{array}{c}\text { Zijlistra et al., } \\
2000\end{array}$ \\
\cline { 1 - 2 } $\begin{array}{c}\text { Fjav/Rjav } \\
\text { (SCAR) }\end{array}$ & 5'-TGCGCGATTGAACTGAGC-3' & \\
\hline
\end{tabular}

The extraction of DNA from females was obtained according to Miller et al., (1988) with some modifications as follows:

\section{Tissue digestion and precipitation of proteins and cell debris}

Six egg masses were crushed in liquid nitrogen until a fine white powder was formed, tissues digestion and precipitation of proteins and cell debris were carried out according to Sambrook et al. (1989).

\section{Precipitation of nucleic acids}

DNA precipitation occurred by adding $750 \mu \mathrm{L}$ of cold absolute ethanol to the supernatant and mixed vigorously for 30 seconds. The tubes were kept in freezer at $20^{\circ} \mathrm{C}$ for 15 minutes to allow better precipitation. Then the tubes were centrifuged at $14000 \mathrm{rpm}$ for 5 minutes. The ethanol and the salts were carefully poured off to avoid disturbing the DNA pellet. The DNA pellet was rinsed by adding $400 \mu \mathrm{L}$ of $70 \%$ ethanol and centrifuging at $14000 \mathrm{rpm}$ for 5 minutes. The tubes were remained inverted for 20 to 30 minutes to allow evaporating of excessive alcohol. The DNA pellet was suspended in $30 \mu \mathrm{L}$ of TE buffer (10mM Tris $\mathrm{HCl}$ and $1 \mathrm{mM}$ EDTA), and stored at 20C for PCR

\section{Polymerase chain reaction}

The polymerase chain reactions (PCR) were carried out using the extracted rootknot nematode DNA as the template. The master mix for $30 \mu \mathrm{L}$ PCR reactions was prepared according to Rychlik (1993) as follows: $17.8 \mu \mathrm{L}$ sterilized distilled water, $3.0 \mu \mathrm{L}$ buffer $(10 \times), 3.0 \mu \mathrm{L} \mathrm{MgCl} 250 \mathrm{mM}), 3.0 \mu \mathrm{L}$ dNTPs $2 \mathrm{mM}, 1.0 \mu \mathrm{L}$ of forward and reverse primers, respectively, 0.2 Taq polymerase and $1.0 \mu \mathrm{L}$ of DNA template $(\mu l)$. All PCR reactions were carried out using Eppendorf mastercycler gradient thermocycler. First, the primers were optimized using a temperature gradient to select the most appropriate temperature. The optimized PCR programs for the different primer combinations were represented according to Rychlik (1993). The PCR products were purified using Kit-Ultra, and the purify was tested by electrophoresis on $1.5 \%$ agarose gels (Paran and Michelmore, 1993). The gel was scanned and analyzed using Gel-pro 31 analyzer (version 3.1, 1998) to compare the sizes of bands against DNA hyper ladder I in Plat (1). 


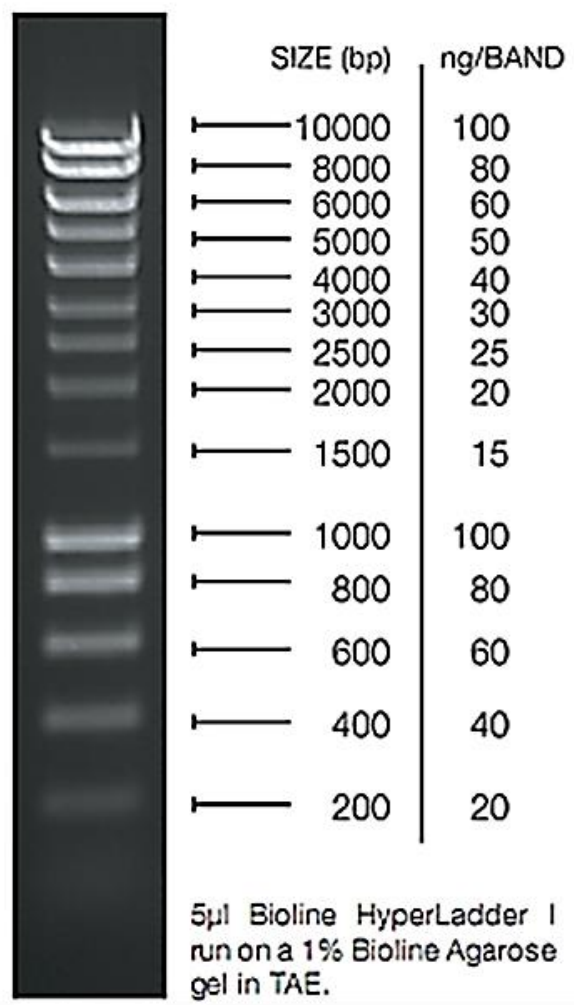

Plat 1: DNA hyper ladder used for estimating band sizes of PCR product visualised on agarose gels.

\section{RESULTS}

All cucumber root samples showed (100\%) infestation with root-knot nematodes under microscopic examination. For molecular identification, even selected primers were tested for the diagnosis and screening of the species specificity morphologically identified as M. javanica. In the present study, only SCAR primers Fjav/Rjav and Far/Rar were positive against DNA isolated from the females of the root-knot nematode $M$. javanica. All tested samples were PCR-positive to $M$. javanica using SCAR primers (Fig. 1). One sample was PCR-positive by using Fjav/Rjav primers (Fig. 2). PCR products were produced one specific band with molecular weight of 670 bp in both primers. The intensity of band was higher using SCAR primers than Fjav/Rjav. On the other side, the mitochondrial primer (C2F3/Mel450R) giving no product with any tested isolate of $M$. javanica, the agarose gel was clear from any bands.

\section{DISCUSSION}

The aim of the present study was assaying the polymerase chain reaction (PCR) with the five mitochondrial and species-specific sequences characterized amplified regions (SCAR) markers to identify the major root-knot nematode $M$. javanica species in Upper Egypt. Some of previous studies indicated that $M$. javanica represents the most prevalence of the root-knot nematodes species in vegetable crops, especially Cucurbitaceae family, in sampling area as a subtropical region, with annual temperatures between $20-40^{\circ} \mathrm{C}$ (Korayem et al., 2008 and Castagnone et al., 2013). Similar results were reported by Nono-Womdim et al. (2002) in a similar climate 
(Tanzania) on some vegetable plants. Contrary to Eisenback et al. (1981) where $M$. javanica was the dominant species of Meloidogyne. This difference may be due to the difference in the nature of the climate (Jonasson et al.,1999 and Sikora et al.,2018). Through the development of taxonomy tools, real-time PCR assays were raised as a suitable device for identification of plant-parasitic nematodes in concurrently with morphological description especially the root-knot nematodes $M$. javanica (Berry et al., 2008 and Fargette et al., 2010). Recently, some nematologists prefer PCR technics for identification of nematodes for some reasons, the most important of them; PCR results are readily available through about three hours which saves time and efforts, compared to conventional methods; the technique can easily be prepared for analysis of many samples at a time; partially, in some scientific analysis, no high nematode taxonomical skills are needed, which save taxonomic expertise and time (BraunKiewnick and Kiewnick, 2018).

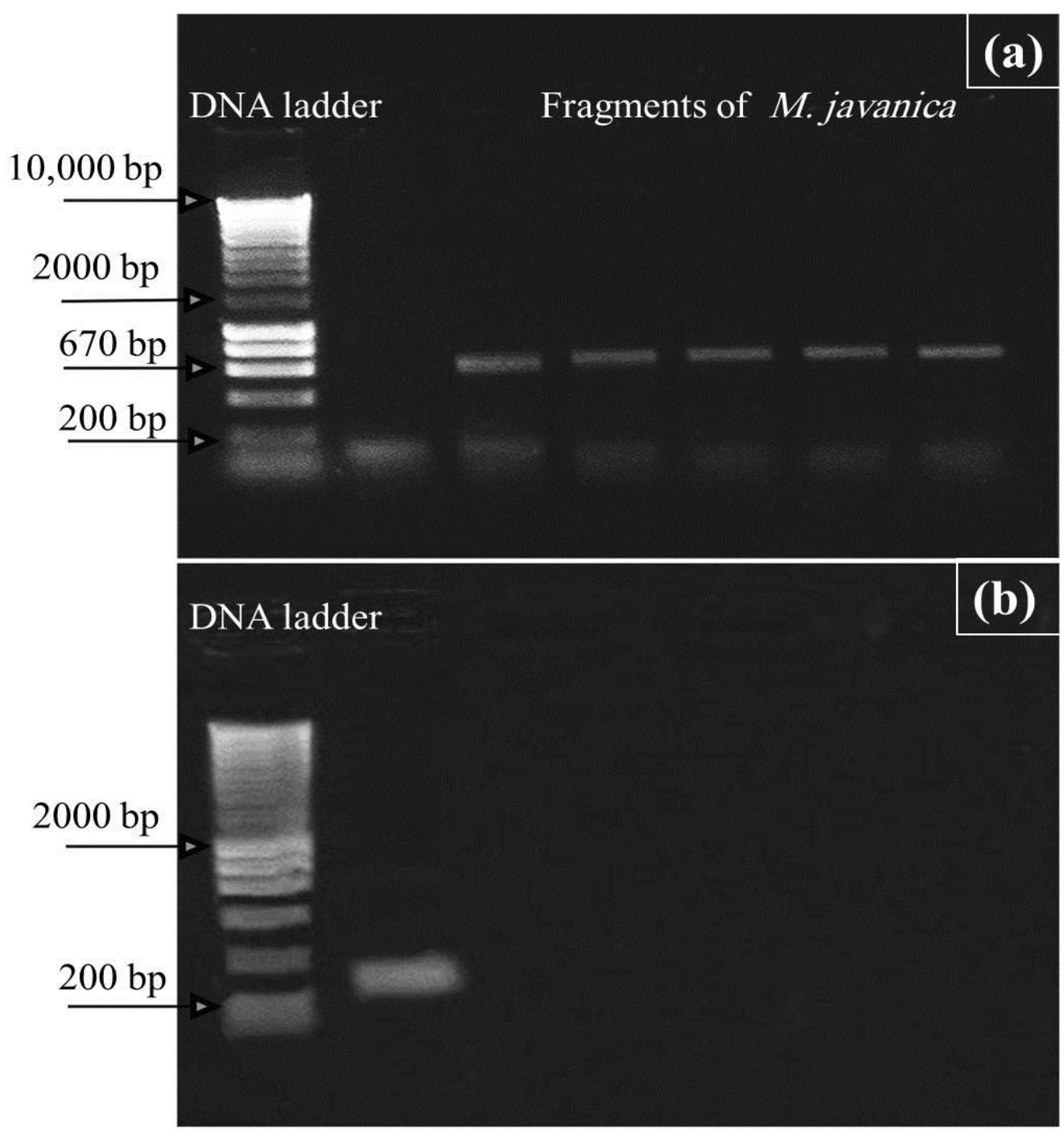

Figure 1: Agarose gel electrophoresis of PCR amplified from extracted DNA from females of $M$. javanica showing: (a) the specific distinct band at $670 \mathrm{bp}$ using speciesspecific mitochondrial SCAR primer; (b) the positive specific band using Fjav/Rjav primer at $517 \mathrm{bp}$. 
The PCR assay for six nematode isolates with the specific SCAR primer Fjav/Rjav clearly produced a specific DNA fragment at $670 \mathrm{bp}$, while using $\mathrm{Mjf} / \mathrm{Mjr}$ primer the band for $M$. javanica was present in lower numbers in the population showing a weak band (517 bp), which was predictable for the $M$. javanica as reported by Berry et al. (2008). Similar findings were noted by Zijlstra et al. (2000) where the SCAR primers clearly produced the DNA fragment at $670 \mathrm{bp}$ more than Mjf/Mjr . It might be due to favorable annealing and a better structure of the template DNA at the downstream located primer binding site (Dong et al., 2001; Randig et al., 2002; Meng et al., 2004). The primer C2F3/Mel450R (mitochondrial) did not give any products with any isolates of tested nematode, this agree with Tesarova et al. (2003) where C2F3/Mel450R primer developed from SEC protein gene sequences belonging to $M$. incognita was not used for M. javanica identification.

Finally, based on the current study the use of SCAR-PCR technique in nematology would be a highly valued technique for identification of the field nematode isolates that need further adaptive investigations.

\section{REFERENCES}

Berry, S. D.; Fargette, M.;Spaull, V. W.; Morand, S., an Cadet, P. (2008). Detection and quantification of root-knot nematode (Meloidogyne javanica), lesion nematode (Pratylenchus zeae) and dagger nematode (Xiphinema elongatum) parasites of sugarcane using real-time PCR. Mol. Cell. Probes 22(3):168-176.

Braun-Kiewnick, A. and Kiewnick, S. (2018). Real-time PCR, a great tool for fast identification, sensitive detection and quantification of important plant-parasitic nematodes. Eur. J. Plant Pathol. 152(2): 271-283.

Castagnone-Sereno, P.; Danchin, E. G.; Perfus-Barbeoch, L.; and Abad, P. (2013). Diversity and evolution of root-knot nematodes, genus Meloidogyne: new insights from the genomic. Annu. Rev. Phytopathol. 51: 203-220.

Castagnone-Sereno, P.; Leroy, F.; Bongiovanni, M.; Zijlstra, C. and Abad, P. (1999). Specific diagnosis of two root-knot nematodes, Meloidogyne chitwoodi and $M$. fallax, with satellite DNA probes. Phytopathol. J. 89(5):380-384.

Cenis, J. L. (1993). Identification of four major Meloidogyne ssp. by random amplified polymorphic DNA (RAPD-PCR)." Phytopathology-New york and Baltimore Then St Paul 83: 76-76.

Chitwood, B. G. (1949). Root-knot nematodes, part I. A revision of the genus Meloidogyne, 1887. Proc Helminthol Soc Wash. 16(2): 90-104.

Chitwood, D. J. (2003). Research on plant parasitic nematode biology conducted by the United States Department of Agricultural Research Service. Pest Manag. Sci.59(6-7): 748-753.

Coyne, D. L.; Fourie, H. H. and Moens, M. (2009). Current and Future Management Strategies in Resource-poor Farming. Root-knot nematodes, p. 444.

De Ley, P.; De Ley, I. T.; Morris, K.; Abebe, E.; Mundo-Ocampo, M.;Yoder, M. and Baldwin, J. G. (2005). An integrated approach to fast and informative morphological vouchering of nematodes for applications in molecular barcoding. Philos. Trans. R. Soc. Lond., B. Biol. Sci 360(1462): 1945-1958.

Dong, K.; Dean, R. A.; Fortnum, B. A.and Lewis, S. A. (2001). Development of PCR primers to identify species of root-knot nematodes: Meloidogyne arenaria, $M$. hapla, M. incognita and M. javanica. Nematropica 31(2): 271-280.

Esbenshade, P. R., and Triantaphyllou, A. C. (1985). Use of enzyme phenotypes for identification of Meloidogyne species. J. Nematol., 17(1): 6. 
Fargette, M.: Berthier, K.: Richaud, M.: Lollier, V.; Franck, P.; Hernandez, A. and Frutos, R. (2010). Crosses prior to parthenogenesis explain the current genetic diversity of tropical plant-parasitic Meloidogyne species (Nematoda: Tylenchida). Infect. Genet. Evol. 10(6): 806-813.

Holterman, M.; van der Wurff, A.; van den Elsen, S.; van Megen, H.,;Bongers, T.; Holovachov, O. and Helder, J. (2006). Phylum-wide analysis of SSU rDNA reveals deep phylogenetic relationships among nematodes and accelerated evolution toward crown clades. Mol. Biol. Evol. 23(9): 1792-1800.

Jonasson, S.; Ruess, L.and Michelsen, A. (1999). Simulated climate change in subarctic soils: responses in nematode species composition and dominance structure. Nematology 1(5): 513-526.

Karssen, G. (2002). The plant parasitic nematode genus Meloidogyne Goldi, 1892 (Tylenchida) in Europe. Brill Academic Publishers, Leiden, The Netherlands, pp.161.

Korayem, A. M.; Noweer, E. M. A. and Mohamed, M. M. M. (2008). Threshold population of Meloidogyne species causing damage to some vegetable crops under certain conditions in Egypt. Egypt. J.Agronematol. 6:217-227.

Meng, Q. P.; Long, H. and Xu, J. H. (2004). PCR assays for rapid and $\forall$ sensitive identification of three major root-knot nematodes, Meloidogyne incognita, M. javanica and M. arenaria. Act. Phytopathol. Sini. 34:204-210.

Miller, S. A. and Martin, R. R. (1988). Molecular diagnosis of plant disease. Annu. Rev. Phytopathol. 26(1): 409-432.

Munthali, M.; Ford-Lloyd, B. V. andNewbury, H. J. (1992). The random amplification of polymorphic DNA for fingerprinting plants. Genome Res. 1(4): 274-276.

Nono-Womdim, R.; Swai, I. S.; Mrosso, L. K.; Chadha, M. L. and Opena, R. T. (2002). Identification of root-knot nematode species occurring on tomatoes in Tanzania and resistant lines for their control. Plant Disease 86(2): 127-130.

Paran, I. and Michelmore, R. W. (1993). Development of reliable PCR-based markers linked to downy mildew resistance genes in lettuce. Theor. Appl. Genet. 85(8): 985-993.

Powers, T. O. and Harris, T. S. (1993). A polymerase chain reaction method for identification of five major Meloidogyne species. J. Nematol. 25(1): 1-6.

Randig, O.; Bongiovanni, M.; Carneiro, R. M. and Castagnone-Sereno, P. (2002). Genetic diversity of root-knot nematodes from Brazil and development of SCAR markers specific for the coffee-damaging species. Genome 45(5): 862-870.

Rychlik, W. (1995). Selection of primers for polymerase chain reaction. Mol. Biotechnol. 3(2): 129-134.

Sambrook J; Fritsch EF; Maniatis T. and Sambrook (1989). Molecular Cloning: A Laboratory Manual. 2nd edition. Cold Spring, NY, USA; Cold Spring Harbor Laboratory Press.

Sasser, J. N. (1954). Identification and host-parasite relationships of certain root-knot nematodes (Meloidogyne spp.). Technical Bulletin. Maryland Agricultural Experiment Station (A-77).

Sikora, R. A.; Coyne, D.; Hallmann, J. and Timper, P. (Eds.). (2018). Plant parasitic nematodes in subtropical and tropical agriculture.CABI, p. 20.

Taylor, D. P. and Netscher, C. (1974). An improved technique for preparing perineal patterns of Meloidogyne spp. Nematologica 20(2): 268-269. 
Tesařová, B.; Zouhar, M. and Ryšánek, P. (2003). Development of PCR for specific determination of root-knot nematode Meloidogyne incognita. Plant Protect. Sci. 39(1):23.

Thomas, W. K.; Vida, J. T.; Frisse, L. M.; Mundo, M., and Baldwin, J. G. (1997). DNA sequences from formalin-fixed nematodes: Integrating molecular and morphological approaches to taxonomy. J. Nematol. 29(3): 250.

Tigano, M.; De Siqueira, K.; Castagnone-Sereno, P.; Mulet, K.; Queiroz, P.; Dos Santos, M. and Carneiro, R. (2010). Genetic diversity of the root-knot nematode Meloidogyne enterolobii and development of a SCAR marker for this guavadamaging species. Plant Pathol. 59(6): 1054-1061.

Zijlstra, C. and Van Hoof, R. A. (2006). A multiplex real-time polymerase chain reaction (TaqMan) assay for the simultaneous detection of Meloidogyne chitwoodi and M. fallax. Phytopathol. 96(11):1255-1262.

Zijlstra, C.; Donkers-Venne, D. T. and Fargette, M. (2000). Identification of Meloidogyne incognita, $M$. javanica and $M$. arenaria using sequence characterised amplified region (SCAR) based PCR assays. Nematol. 2(8): 847853.

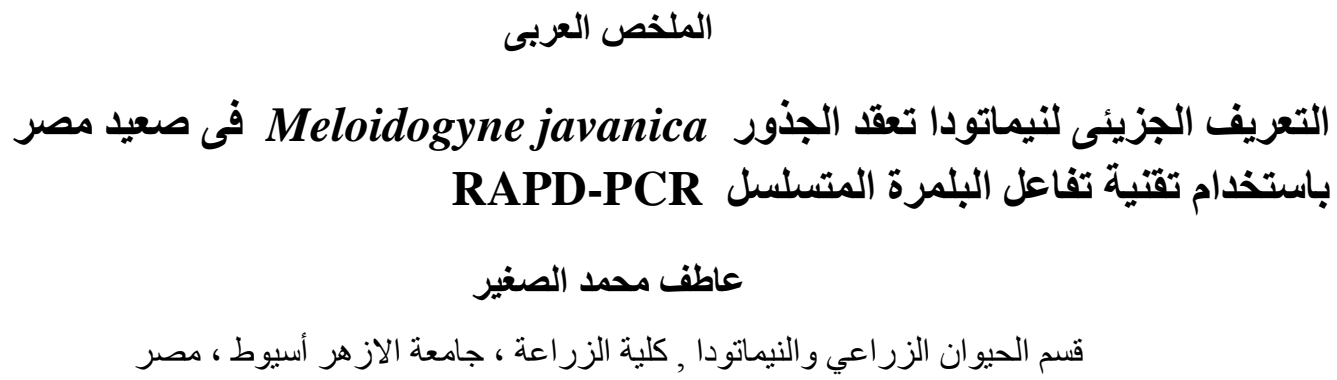

تم في هذه الدر اسة عزل الحمض النووي الريبوزي منقوص الأكسجين (DNA) من الاناث البالغة لنيماتودا تعقد الجذور من النوع Meloidogyne javanica المتطفلة على نباتات الخيار في محافظة اسيوط (صعيد مصر) , لتشخيص هذا النوع اعتمادا على تفاعل البلمرة المتسلسل PCR معتمدا على المناطق المتضاعفة من خلال الفحص المعتمد على التضاغف العشو ائي متعدد الاشكال (RAPD-PCR) للا DNA ماستخدام اربعة انوع من البادئات مندرجة تحت المجموعتين (Mitochondrial و SCAR ). اشارت النتائج الى ان استخدام تقنية RAPD-PCR هى طريقة فعالة لتعريف هذا النوع من نيماتودا التعقد , كما اشارت النتائج الى ان البادئات

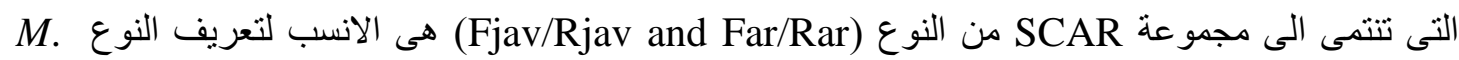
javanica على العكس من بادئات مجمو عة Mitochondrial والذى اعطى حجم ازو اج قاعدة اقل بشكل معنوى وبالتالى لم تعطى نتائج محددة لهذا النوع من نيماتودا تعقد الجذور. 